\title{
НЕМОТИВОВАНІ СКЛАДНОНУЛЬСУФІКСАЛЬНІ АД'СКТИВИ З ДРУГИМ НЕСОМАТИЧНИМ КОМПОНЕНТОМ НА ОЗНАЧЕННЯ ЛЮДИНИ
}

У статті окреслено дериваційні, структурно-семантичні й функціональні властивості узуальних та індивідуально-авторських ад'єктивних композитів з матеріально не вираженим суфіксом з першим прикметниковим та другим іменниковим компонентом, що вказують на ознаку за віднесенням до людини і мають у своїй основі несоматичне поняття антропонімічного та неантропонімічного характеру. 3'ясовано їх місце, роль та сфери функціонування в сучасній українській мові.

Ключові слова: нульовий суфікс, формант, нульсуфіксальний спосіб словотвору, ад’єктивний складнонульсуфіксальний композит, несоматичне поняття, мотивований, напівмотивований, немотивований дериват.

Mizina O. I. , Isaienko T. K. Opaque Complex-Zero-Suffixal Adjectives with the Second Nonsomatic Component Aimed at the Definition of a Human. The article outlines the derivational, structural-semantic and functional properties of usual and individual-authorial adjectival composites with a materially non-marked suffix with the first adjectival and the second substantive component, denoting a characteristic of a person and having basically non-somatic notion of anthroponymic and non-anthroponymic character.

Adjectival composites with the first adjectival and the second substantive component occupy a noticeable place among adjectival derivatives formed with the participation of a zero-suffix formant. So far, composites of the investigated word-formative type in general and complex-zero-suffixal adjectives with a materially non-marked formant in particular have never been the subject of a special study, which determines the relevancy of the chosen topic.

The purpose of the article is to define the word-usage frequency of the corresponding complex-zero-suffixal adjectival derivatives, to find out their place, role, specificity of functioning in the modern Ukrainian language, to elucidate their derivational, structural-semantic and functional properties. The achievement of the stated goal involves solving of the following tasks: to determine the peculiar properties of the motivation of the derivatives under study, to analyze the external valency, as well as to find out their pragmatic potential.

The conducted analysis of the complex-zero-suffixal adjectival derivatives has revealed the following tendencies: among the composites of the lexical-semantic group being studied, only opaque (non-motivated) composites function actively, while we have not noticed motivated and semi-motivated lexical items among them. Complex-zero-suffixal adjectives have broad co-occurrence and extensively implement their figurative (allegoric) meanings. On the whole, the corresponding composites, entering into distribution with the nouns denoting a person, gain pejorative meaning, becoming the markers of negative evaluation and disparagement. Sometimes it happens that the units under study come into distribution with the nouns denoting the phenomena of nature, realizing a new figurative idiomatic meaning - "the revival" of the nonliving, thus replenishing the corpus of epithets and contributing to the enrichment of the poetic language imagery.

Key words: zero suffix, formant, zero-suffixal word-building method, adjectival complex-zero-suffixal composite, non-somatic notion, motivated, semi-motivated, opaque derivative.

\section{Вступ}

Серед прикметникових дериватів, що утворені за участі форманта з нульовим суфіксом помітне місце посідають ад’єктивні композити з першим прикметниковим та другим іменниковим компонентами. Дотепер складнонульсуфіксальні деривати з матеріально не вираженим формантом, зокрема 
й композити досліджуваного словотвірного типу, утворені за структурою «прикметник (ПР) + іменник (I) + нульовий суфікс (ø) + закінчення -ий», а саме ад'єктиви, утворені шляхом основоскладання, що вказують на ознаку за віднесенням до людини й мають у своїй основі несоматичне поняття антропонімічного та неантропонімічного характеру, не були предметом спеціального дослідження, чим і зумовлена актуальність обраної теми.

У сучасній українській дериватології одним з дискусійних залишається питання про способи словотвору з формантом, до складу якого входить матеріально не виражений суфікс. Сутність його полягає в тому, що до твірної основи додається нульовий суфікс та нульове чи субстанційно виражене закінчення, які в сполученні становлять формант, що і $є$ носієм словотвірного значення.

Структурно-семантичні типи композитів з першим прикметниковим та другим іменниковим компонентом та з матеріально не вираженим суфіксом $€$ досить продуктивними. Деривати, що мають один опорний компонент, у якому конкретизується значення всього композита, а другий зазвичай стоїть у постпозиції, несучи більш узагальнену інформацію про носія першої ознаки, утворені шляхом основоскладання зі сполучною голосною (інтерфіксом) та нульовим суфіксом на базі словосполучення, що має в основі: 1) семантику кольору, С3 «ознака за кольором того, що названо мотивуючим іменником»; 2) іншу семантику (окрім колірної), С3 «ознака за властивостями того, що названо мотивуючим іменником». Найчастотнішими серед утворень такого типу є композити, постпозиційним компонентом яких виступають іменники із соматичним значенням (голова, нога, око, палець, рука та ін.).

Структурно-семантичні та функціонально-стильові властивості складнонульсуфіксальних ад'єктивів з другим соматичним компонентом на означення зовнішньої та внутрішньої характеристики людини було розглянуто в окремих статтях (Гаращенко \& Мізіна, 2018; Mizina, 2016). Композити, що вказують на ознаку за віднесенням до людини та мають в іменниковій основі назву несоматичного антропонімічного поняття (голос, дуx, сльози) й неантропонімічного характеру (сила, вага), дотепер не розглядались, що зумовлює певний дослідницький інтерес.

В українському мовознавстві складним прикметникам, що стали засобом творення традиційних та індивідуально-авторських епітетів, приділено значну увагу. Складні прикметники як засіб творення традиційних та індивідуально-авторських новотворів вивчались у різних аспектах, що спричинило появу низки словників авторських неологізмів (Г. Віняр і Л. Шпачук, Г. Вокальчук, Ж. Колоїз, А. Нелюба), але попри це складнонульсуфіксальні прикметникові композити на означення характеристики людини з першим прикметниковим та другим іменниковим компонентом досліджувалися тільки принагідно в контексті розгляду інших проблем (роботи Т. Біленко, Н. Гаврилюк, Г. Вокальчук, О. Рудь, О. Жижоми та ін.). Аналізуючи композитні деривати, утворені на базі прикметниково-іменникового сполучення, у загальному масиві композитів, більшість мовознавців називає 
їх дериватами, що утворилися шляхом композиції основ без участі афіксів (Г. Вокальчук, О. Рудь та ін.), з огляду на формант, до складу якого входить нульовий суфікс, ці композити не вивчалися.

Мета статті - виявити активність уживання відповідних складнонульсуфіксальних ад'єктивних дериватів, з'ясувати їх місце, роль, специфіку функціонування в сучасній українській мові, дериваційні, структурно-семантичні та функціональні можливості. Досягнення висунутої мети передбачає розв'язання таких завдань: визначити особливості мотивації досліджуваних дериватів, дослідити зовнішню валентність та з'ясувати їх прагматичний потенціал. Матеріалом для дослідження послужила картотека, укладена шляхом суцільної вибірки зі словника української мови (СУМ, 1970-1980) (узуальні одиниці) та словників інновацій (Вокальчук, 2004), (Вокальчук, 2008), (Нелюба, 2010), (Нелюба, 2007), (Рудь, 2001).

\section{Методи й методики дослідження}

На сучасному етапі у процесі дослідженні дериваційно-номінативних процесів у складних словотвірних одиницях у мовознавстві застосовують метод перифраз, запропонований В. Дорошевським і розроблений А. Дем'янюк, О. Кубряковою, Н. Клименко та ін. Під час здійснення семантико-словотвірного аналізу складнонульсуфіксальних ад'єктивних утворень метод перифраз дає змогу встановити синтаксичні кореляти, які визначають формальну похідність, з'ясувати семантичну похідність та встановити відношення між твірними та похідним словом, між формантом та твірною основою, зокрема виділити мотивовані, напівмотивовані та немотивовані деривати (Клименко, 1984: 51-52). До мотивованих віднесено слова, що вільно перифразовуються в речення, виникають як сума значень компонентів, поєднаних у слові за певною словотвірною моделлю, схемою: миловидий - перифраз «той, що має миле лице, обличчя»; до напівмотивованих - ті, для перифразування яких потрібні додаткові слова, що не фіксуються в основі деривата, наприклад, дериват бистроокий має значення «із жвавими очима, з гострим швидким поглядом»; до немотивованих - лексеми, що не перифразовуються співвідносними за основою словами й пояснюються виключно іншими словами: напр., вузьколобий не просто «той, хто має вузький лоб», а «той, хто не може піднятися вище своїх особистих або класових інтересів; обмежений» [СУМ, 1970-1980: 1: 785].

Такі значення дериватів зумовлені не тільки семантикою слів, що їх безпосередньо мотивують, а й упливом на них типового лексичного й синтаксичного оточення твірних слів. Отже, існують два види мотивації, коли одне слово мотивує інше й коли похідне мотивується певною синтаксичною конструкцією, до якої безпосередньо входить мотивуюче слово й де воно виступає в звичному для нього поєднанні з іншими словами (Клименко, 1984: 7).

\section{Результати та дискусії}

Семантико-словотвірний аналіз складних слів, в основу якого покладено метод перифразування, серед мотивованих та напівмотивованих композитів, що означують людину та мають в іменниковій основі назву 
несоматичного антропонімічного поняття (голос, дух, сльози) й неантропонімічного характеру (сила, вага), відповідних дериватів не виявив.

До відповідної лексико-семантичної групи, яку репрезентовано чотирма підгрупами, належать лише немотивовані деривати:

1. Композити, які мають семантичний компонент «здатність піддаватися впливу». Досліджувані одиниці цієї лексико-семантичної підгрупи репрезентовані дериватами з постпозиційною основою -духий, що вступають між собою в антонімічні (м'якодухий/твердодухий) та синонімічні (слабодухий, легкодухий, слабосилий) зв'язки та мають метафоричний характер: Україния зображено полохливим і м'якодухим, розмазнею-ганчіркою. В той час як інші герої демонструють майже нордичний характер (О. Редченко); Вчення плоди стануть грунтовними лиш в того шляхетного, хто твердодухий та владний (Лунь Юй); Якийсь слабодухий Гнат у сім '̈̈ (К. Гордієнко) (СУМ, 1970-1980: 9: 343); Ось він ввесь немов живий. - Любий, щедрий та сердечний Патріот наш молодий. Легкодухий і безпечний (М. Вороний) (Рудь, 2001: 143).

До цієї ж підгрупи досліджуваних дериватів віднесено індивідуальноавторські складнонульсуфіксальні ад'єктиви із постпозиційними компонентами -духий, -душий та препозиційними основами дрібно-, криво-, куцо-, слабо-, синонімічні до узуальних складнонульсуфіксальних ад’єктивних дериватів у(в)богодухий, що є засобами створення негативної характеристики людини, напр.: дрібнодухий: ... залишилося після того винищення дрібнодухе населення; воно народжує ще менш дрібнодухих, у яких органи творчості атрофовано, а безвідмовно працює лише фізіологія живлення та виділення (з газети) (Нелюба, 2010: 28); криводухий: В таких хапуг і трутнів, Як ией Авило П'явка, На підлих, криводухих, На лицемірів ставка. (П. Глазовий); криводухий мартовський кіт [про хтивого чоловіка] (з газети); куцодуший: Нині нащадки його куцодуші / 3 болота золото роблять... (В. Кучерук) (Вокальчук, 2008: 116); слабодухий: В їх ідеолога нема. Нема з ким школи утворити. - Наївні, слабодухі дітu! (П. Тичина) (Рудь, 2001: 52-53). Ад'єктиви з іменниковими основами -духий, -душий можуть сполучатися також з іменниками, що номінують абстрактні поняття: чужодуха анклавність: Таку ж чужодуху, російськаомовну анклавність демонструють $і$ заштатні наші Черкаси наплодженими в часи незалежності російськомовними газетками (з газети) (Нелюба, 2010: 108], мертводуша короткозорість: О ви, з очима тінними! - кроти / бояться світла так! Я вас не рушу! / Яких жее гір долать мені хребти - / короткозорість вашу мертводуиу?! (С. Йовенко) (Вокальчук, 2004: 274).

2. Складнонульсуфіксальні ад'єктивні деривати, пов'язані з ФО «тонкий на сльозу». Узуальний композит тонкосльозий означує плаксиву, схильну до плачу людину, яка може легко розплакатися з будь-якого приводу, напр.: Що мати була дуже тонкосльоза, ми знали всі добре (О. Довженко) (СУМ, 1970-1980: 10: 191).

Подібність крапель дощу до сліз істоти означує індивідуально-авторський новотвір ніжносльозий, що заснований на метафоричному перенесенні: Летять хмарини ніжносльозі, Летять літа на бомбовозі (І. Драч) (Вокальчук, 2004: 311). 
3. На метафоричному порівнянні форми крил, що нагадують дугу («округла крива лінія»), птаха, який швидко летить («з прудкими крилами») заснований індивідуально-авторський складнонульсуфіксальний ад'єктивний дериват прудкодугий у сполученні з іменником-соматизмом крила, напр.: Відірву од вітру прудкодугі крила I майну до тебе без доріг, мостів... (В. Ярмолюк) (Вокальчук, 2008: 147).

За зовнішньою подібністю до тварини та частин ії тіла грунтуються індивідуально-авторські ад'єктивні композити, що означують людину та частини іiї тіла: мишачохвостий (у значенні «тоненький, схожий на мишачий хвіст»): ... дві мишачохвості коси (О. Забужко) (Вокальчук, 2004: 276); довгоглистий (у значенні «зовні схожий на довгого глиста»): Щось нашкрябував пером аж тряслися патлі довгі при блокноті, клишоногий, трохи п'яний, довгоглистий, прикодловий особистий того злодія шкрябак (В. Дацюк) (Нелюба, 2007: 35).

До немотивованих оказіоналізмів відносимо й композит товстом'ясий у дистрибуції з іменником, що номінує назву частини тіла тварини воло, цей дериват маркує негативну оцінку, означуючи міфічну істоту, схожу на тварину, напр.: Сопіння, стогін, виляски навколо, Вже потвор сморід з рота вирига і набік хилить товстом'ясе воло (М. Драй-Хмара) (Вокальчук, 2004: 449).

4. На ознаку за віднесенням до звучання, джерела звуку, звукової наповнюваності вказують композити, що в другій основі містять назву частини тіла істоти, яка входить до складу голосового апарату та бере участь у голосоутворенні (губи (старосл. уста, вуста), язик, рот, горло, груди). Сполучаючись $з$ іменниками різної семантики, ці композити набувають різноманітних значень: єдиновустий народ («утворений великою кількістю голосів (уст), що зливаються в один звук»): ...вгорі де немає Бога майорять / слова ще єдиновустого народу (I. Калинець) (Вокальчук, 2004: 200); натхненноустий чужоземець: Коли ось серием линеш за натхненноустим / чужоземием, / схились, далека сестро, над дорогоцінний струмінь Слова... (Б.-І. Антонич) (Вокальчук, 2004: 294). Інколи складнонульсуфіксальні композити співвідносяться з морфологічно простими прикметниками: натхненноустий $=$ натхненний.

\section{Висновки}

Здійснений аналіз складнонульсуфіксальних ад'єктивних дериватів виявив такі тенденції: серед композитів досліджуваної лексико-семантичної групи активно функціонують лише немотивовані композити, мотивованих і напівмотивованих лексем серед них не зафіксовано. Складнонульсуфіксальні ад'єктивні деривати досліджуваної лексико-семантичної групи мають широку сполучуваність й активно реалізують свої переносні значення. Здебільшого відповідні композити, вступаючи в дистрибуцію з іменниками, що номінують людину, набувають пейоративного значення, стаючи маркерами негативної оцінності та зневажливого ставлення. Трапляються випадки, коли досліджувані ад’єктиви вступають у дистрибуцію з іменниками, що номінують абстрактні явища або явища природи, реалізуючи нове переносне образне значення - «оживлення» неживого, поповнюючи тим самим корпус епітетів і сприяючи збагаченню образної системи поетичної мови. 
У перспективі передбачено розглянути структурно-семантичні особливості нульсуфіксальних однокореневих ад’єктивів.

\section{ЛIТЕРАТУРА}

1. Вокальчук Г. М. Короткий словник авторських неологізмів в українській поезії XX століття. Авторський неологізм в українській поезії XX століття (лексикографічний аспект) : монографія / за ред. А. П. Грищенка. Рівне: Науково-видавничий центр «Перспектива», 2004. С. 94-491. 2. Гаращенко Л. Б., Мізіна О. І. Структурно-семантичні та функціонально-стильові властивості складнонульсуфіксальних ад’єктивів на означення зовнішньої та внутрішньої характеристики тварин. Наукові записки Національного університету «Острозька академія». Серія «Філологія». Острог : Видво НаУОА, 2018. Вип. 1(69). Ч. 1. 270 с. С. 100-103. 3. Клименко Н. Ф. Словотворча структура і семантика складних слів у сучасній українській мові. Київ : Наук. думка, 1984. 251 c. 4. Mizina O. Structural-semantic and functional-stylistic properties of complex zero-suffix adjectives with the meaning of the person's external characteristics in the modern ukrainian language. Вісник Маріупольського держсавного університету. Серія: Філологія. Маріуполь : МДУ, 2016. Вип. 14. С. 95-103. 5. Нелюба А., Нелюба С. Лексико-словотвірні інновації (2004-2006) : словник. Харків : Майдан, 2007. 144 с. 6. Нелюба А. Лексико-словотвірні інновації (2008-2009) : словник. Харків: ХІФТ, 2010. 116 с. 7. «Регіональний» словник поетичних неолексем (Рівненщина) / відп. ред. Г. М. Вокальчук. Вид. 2-е, випр. і доп. Острог: Вид-во НаУ «Острозька академія», 2008. 192 с. 8. Рудь О. Поетичне слововживання складних прикметників та дієприкметників. Суми: СумДПУ ім. А. С. Макаренка, 2001. 270 с. 9. Словник української мови : в 11 т. / АН УРСР, Ін-т мовознавства ім. О. О. Потебні; /гол. ред. І. К. Білодід/. - Київ : Наук. думка, 1970-1980.

\section{REFERENCES}

1. Vokaljchuk, Gh. M. (2004). Korotkyj slovnyk avtorsjkykh neologhizmiv v ukrajinsjkij poeziji KhKh stolittja [Brief dictionary of authorial neologisms in Ukrainian poetry of the twentieth century]. Avtorsjkyj neologhizm v ukrajinsjkij poeziji XX stolittja (leksykoghrafichnyj aspekt) - Author neologism in Ukrainian poetry of the twentieth century (lexicographic aspect)] A. P. Ghryshhenko (Ed.), (pp. 94-491). Rivne: «Perspektyva» [in Ukrainian]. 2. Gharashhenko, L. B. \& Mizina, O. I. (2018). Strukturno-semantychni ta funkcionaljnostyljovi vlastyvosti skladnonuljsufiksaljnykh ad'jektyviv na oznachennja zovnishnjoji ta vnutrishnjoji kharakterystyky tvaryn. [Structural-semantic and functional-stylish peculiarities of composite nought-suffix adjectives for the determination of external and internal animal features]. Naukovi zapysky Nacionaljnogho universytetu «Ostrozjka akademija». - Scientific proceedings of the National University of «Ostroh Academy». Series Philology, 1(69) (part 1), (pp. 100-103). Ostrogh: NaUOA [in Ukrainian]. 3. Klymenko, N. F. (1984). Slovotvorcha struktura i semantyka skladnykh sliv u suchasnij ukrajinsjkij movi [Word-building structure and semantics of complex words in modern Ukrainian language]. Kyiv: Nauk. dumka [in Ukrainian]. 4. Mizina, O. (2016). Srukturno-semantychni ta funkcionaljno-styljovi vlastyvosti skladnonuljsufiksaljnykh ad'jektyviv na oznachennja zovnishnjoji kharakterystyky ljudyny v suchasnij ukrajinsjkij movi [Structural-semantic and functional-stylistic properties of complex zero-suffix adjectives with the meaning of the person's external characteristics in the modern ukrainian language]. Bulletin of Mariupol State University. Series: Philology, (Issue 14), (pp. 95-103). Mariupolj: MDU [in Ukrainian]. 5. Neljuba, A. \& Neljuba, S. (2007). Leksyko-slovotvirni innovaciji (2004-2006): slovnyk [Lexicon-word-building innovations (2004-2006): dictionary]. Kharkiv: Majdan [in Ukrainian]. 6. Neljuba, A. (2010). Leksykoslovotvirni innovaciji (2008-2009): slovnyk [Lexicon-word-building innovations (2008-2009): 
dictionary]. Kharkiv: KhIFT [in Ukrainian]. 7. Vokaljchuk, Gh. M. (2008). "Reghionaljnyj» slovnyk poetychnykh neoleksem (Rivnenshhyna) ["Regional» dictionary of poetic neolectos (Rivne region)] Ostrogh: «Ostrozjka akademija» [in Ukrainian]. 8. Rudj, O. (2001). Poetychne slovovzhyvannja skladnykh prykmetnykiv ta dijeprykmetnykiv [Poetic use of words of complex adjectives and adjectives]. Sumy : SumDPU im. A. S. Makarenka [in Ukrainian]. 9. Bilodid, I. K. (Ed.). (1970-1980). Slovnyk ukrajinsjkoji movy [Dictionary of the Ukrainian language].(Vols. 1-11). Kyiv: Nauk. dumka [in Ukrainian].

Мізіна Ольга Іванівна - кандидат філологічних наук, доцент, доцент кафедри українознавства, культури та документознавства, Полтавський національний технічний університет імені Юрія Кондратюка; Першотравневий проспект, 24, Полтава, 36011, Україна.

Tel.: +380950954664

E-mail: olamizina@gmail.com

https://orcid.org/0000-0002-1988-6353

Mizina Olga Ivanivna - PhD in Philology, Associate Professor, Department of Ukrainian Studies, Culture and Documentation, Yuri Kondratyuk Poltava National Technical University; Pershotravnevyi Av., 24, Poltava, 36011, Ukraine.

Ісаєнко Тетяна Костянтинівна - кандидат педагогічних наук, доцент, доцент кафедри українознавства, культури та документознавства, Полтавський національний технічний університет імені Юрія Кондратюка; Першотравневий проспект, 24, Полтава, 36011, Україна.

Tel.: +380956650258

E-mail: isaenko0258@gmail.com

https://orcid.org/0000-0003-1135-0623

Isaienko Tetiana Konstiantynivna - PhD in Pedagogics, Associate Professor, Department of Ukrainian Studies, Culture and Documentation, Yuri Kondratyuk Poltava National Technical University; Pershotravnevyi Av., 24, Poltava, 36011, Ukraine.

Надійшла до редакції 31 березня 2019 року 